\title{
An Analysis of the Greenhouse Gas Emissions by the Re-Liquefaction of Boil-Off Gas of LNG Storage Tank
}

\author{
Gang Sun ${ }^{1}$, Shengchun Liu' ${ }^{2 *}$ Xueqiang Li ${ }^{2}$ \\ ${ }^{1}$ China Aviation Planning and Construction Development Co., Ltd., Beijing, China \\ ${ }^{2}$ Tianjin Key Laboratory of Refrigeration Technology, Tianjin University of Commerce, Tianjin, China \\ Email: liushch@tjcu.edu.cn
}

Received 10 July 2015; accepted 10 August 2015; published 13 August 2015

Copyright (C) 2015 by authors and Scientific Research Publishing Inc.

This work is licensed under the Creative Commons Attribution International License (CC BY).

http://creativecommons.org/licenses/by/4.0/

(c) (†) Open Access

\begin{abstract}
The pressure in liquefied natural gas (LNG) storage tank continues to increase due to the heat transfer from ambient air to low temperature LNG, which raises safety concerns. Accordingly, there is increasing interest to explore the technical approaches capable of recovering Boil-off Gas (BOG) and even eliminating the ventilation of LNG storage tank. This research numerically analyzed the greenhouse gas emissions of the re-liquefaction of BOG using the following four approaches: 1) a Claude cycle driven by electrical motor with the electricity produced by burning coal; 2) a Claude cycle driven by a gas turbine fuelled by BOG released; 3) a Claude cycle driven by a SI engine fuelled by gasoline; 4) burning nature gas directly released by BOG. The impact of heat transfer coefficient, LNG tank configuration, size, and percentage of LNG stored in tank on the rate of BOG and energy needed for the re-liquefaction of methane vapor were investigated. The greenhouse gas emissions (GGE) was examined and compared. The data presented in this paper provide guideline for the management of pressure development in LNG storage tank.
\end{abstract}

\section{Keywords}

LNG, Boil-Off Gas, Re-Liquiefication, Greenhouse Gas Emissions

\section{Introduction}

With the continuous development of human economy and increasing of the energy consumption, the "global warming”, “ecosystem degradation” and other problems caused by the aggravate emissions of the greenhouse

${ }^{*}$ Corresponding author.

How to cite this paper: Sun, G., Liu, S.C. and Li, X.Q. (2015) An Analysis of the Greenhouse Gas Emissions by the Re-Liquefaction of Boil-Off Gas of LNG Storage Tank. Energy and Power Engineering, 7, 354-364. 
gas are serious threatening to the survival and development of mankind [1]. At the same time, the sustainable development of China's economy and the rapid growth of energy consumption led to a sharp increase in greenhouse gas emissions, due to the reason that greenhouse gas emissions has climbed to 6.8 billion tons in 2014, which is $24.3 \%$ of the whole world emissions, China has become the world's second-largest energy consumer country and the second largest carbon emitter [2].

LNG is natural gas (NG) that has been processed and condensed in to a liquid at almost atmospheric pressure by cooling it to $-163^{\circ} \mathrm{C}$. LNG is about $1 / 614^{\text {th }}$ the volume of natural gas at standard temperature and pressure [3]. The trend in power generation of shifting away from coal to reduce the adverse effects of $\mathrm{CO}_{2}$ and other gas emissions on the environment has made steep demand on the supply of natural gas. Because of these developments, natural gas is now the fastest growing energy source and in the last five years, the growth rate in LNG production has been about $60 \%$ with the current annual output now touching 260 million tons. Industry estimates also indicate that this trend may continue for another several years. The accelerated growth in LNG business is not difficult to visualize as there is crying demand for clean energy all over the world, and particularly in the developing countries [4].

Recently, there has been a significant increase in the level of interest in environmentally friendly and economically viable solutions for the transport of Liquefied Natural Gas (LNG). The development of liquefaction process for Liquefied Natural Gas boil-off re-liquefaction plants will be addressed to provide an environmentally friendly and cost effective solution for gas transport.

Although most LNG storage tanks are equipped with highly efficient insulation, heat leak from outside occurs unavoidably. Evaporation at the interface of LNG by heat leak leads to the self-pressurization of the LNG storage tank [5]. For the safety consideration, some methods used to keep the pressure of LNG tank under the pressure limit. In order to reduce the radiation fluxes, two techniques are used light or rigid screens cooled through thermal contact with the neck, as well as super isolation. These complex heat transfers have led several researchers to investigate this field, in order to verify experimentally these heat gains to the cryostat [6]. The heat transfer is equivalent to the heat needed for vaporization from the surface of LNG. The gas vaporized from the surface is called BOG (Boil off Gas), and the boil-off rate is nearly constant. The control of LNG pressure using PRV is the most widely used methods controlling the pressure of LNG in LNG tank. But pressure relieve valve is open and ventilate methane to ambient air, and it is impact on environment because the methane is green house gas (GHG), and it is also waste energy though evaporation of Liquid LNG to vapor can cool LNG by evaporation. During normal operation, 0.1 vol\% of the LNG in the tank is evaporated daily as boil-off gas (BOG) by heat transfer from the surroundings. Too much BOG inside a storage tank brings about safety issues, and too little BOG caused by overrunning of the BOG compressors may mean unnecessary waste of energy [7]. Instead of the common application by using the boil-off gas as fuel, the LNG BOG re-liquefaction system establishes a solution to liquefy the boil-off gas and the LNG back to the cargo tanks. The LNG re-liquefaction system has some merit such as large savings in total fuel consumption and improved propulsion redundancy [8]. It can be obtained higher system efficiency by using the expander and achieve lower temperature by using the expansion valve [9].

Numerous researches have been conducted to investigate the approaches capable of re-liquefying the BOG to LNG. For example, Baek [10] gives an investigation of novel LNG re-liquefaction process where the cold exergy of sub-cooled LNG is utilized to recondense the vaporized light component of LNG after it is separated from the heavier component in a phase separator. Younggy Shin [11] designs a re-liquefaction process based on the reverse Brayton cycle, and analyzes its static thermodynamic states at the design BOG load. To make the cycle work for any BOG load, an idea was sought that would achieve a heat balance with the work extracted by the expander. Chang Kwang Pil [12] gives an introduction to reliability assessment of re-liquefaction systems for boil-off gas (BOG) on LNG carriers with focus on redundancy optimization and maintenance strategies. Hoseyn Sayyaadi [13] [14] researched that onboard boil-off gas (BOG) re-liquefaction system as a cryogenic refrigeration cycle is utilized in order to re-liquefy the BOG and returns it to the cargo tanks instead of burning it. He also performed the optimization in order to maximize the exergetic efficiency of plant and minimize the unit cost of the system product (refrigeration effect), simultaneously. Thermodynamic modeling is performed based on energy and exergy analyses, while an exergoeconomic model based on the total revenue requirement (TRR) are developed. Javier Romero [15] analyses the Brayton cooling cycle for the reliquefaction of the boil off on liquefied natural gas (LNG) vessels. Above all, there are many kinds of liquefied natural gas: such as Precooled Joule-Thomson (JT) Cycle, Claude cycle, Cascade Cycle, Mixed-Refrigerant Cycle(MRC), Stirling Cycle and 
so on [16]. BOG of LNG recover technology described above mainly is focus on the coefficient of performance (COP). For using different systems to produce the same cooling capacity which is used to the boil-off gas re-liquefaction, the coefficient of performance each system cannot correctly reflect the real performance of the unit. Using the primary energy ratio to compare four kinds of different boil-off gas re-liquefaction systems will be comparable. No researcher do this analyze on greenhouse gas emissions. So in this paper, in order to find the optimization cycle for BOG re-liquefaction, it is mainly analyzed about three different power input (electricity, gas turbine and internal combustion engine) for Claude Cycle to liquefying natural gas. All the analyses are based on the greenhouse gas emissions (GGE).

\section{Greenhouse Gas Emissions}

\subsection{Burning NG Directly Released by BOG}

The pressure in LNG storage tank may raises safety concerns. In order to make the tank in a safe operating range, some methods used to keep the pressure of LNG tank under the pressure limit. Burning NG directly released by BOG is a method to solve safety concerns, but this method will produce greenhouse gas. In this paper, the greenhouse gas emission through this method will be calculate and elaborate.

\subsection{Re-Liquefaction System}

Because of the heat transfer and the input/output of LNG tank, the internal pressure of the tank will change accordingly. The boil-off gas in LNG tank should be treated when the pressure reach the safety value. From the view point of environmental protection, the direct discharge of gaseous NG is not the best solution method. The boil-off gas re-liquefaction and feed back to the LNG tank is the widely used way nowadays. In this paper, it is introduced that four re-liquefaction system.

As shown in Figure 1, the BOG will be condensed in BOG condenser. For this system, some cooling capacity will be given to the heat exchanger. There are two methods which can produce cooling capacity for the BOG condenser. One is local system that the cooling capacity will produce by Claude cycle which is driven by the different power; the other is indirectly cooling making system that the liquid nitrogen will be feed to the BOG condenser directly. All the system will be described as follows.

\subsubsection{Electricity Driven Claude Cycle}

Applying Claude cycle which is driven by the power of electricity to make cooling capacity is showed in Figure 2 .

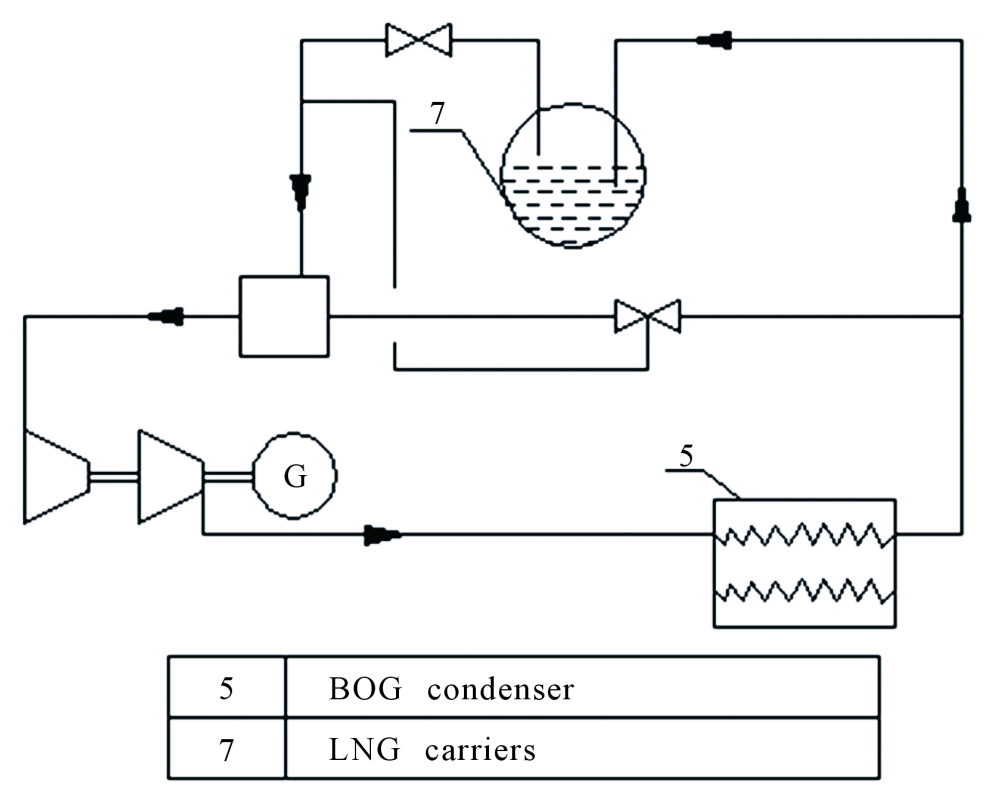

Figure 1. The main BOG re-liquefaction system. 


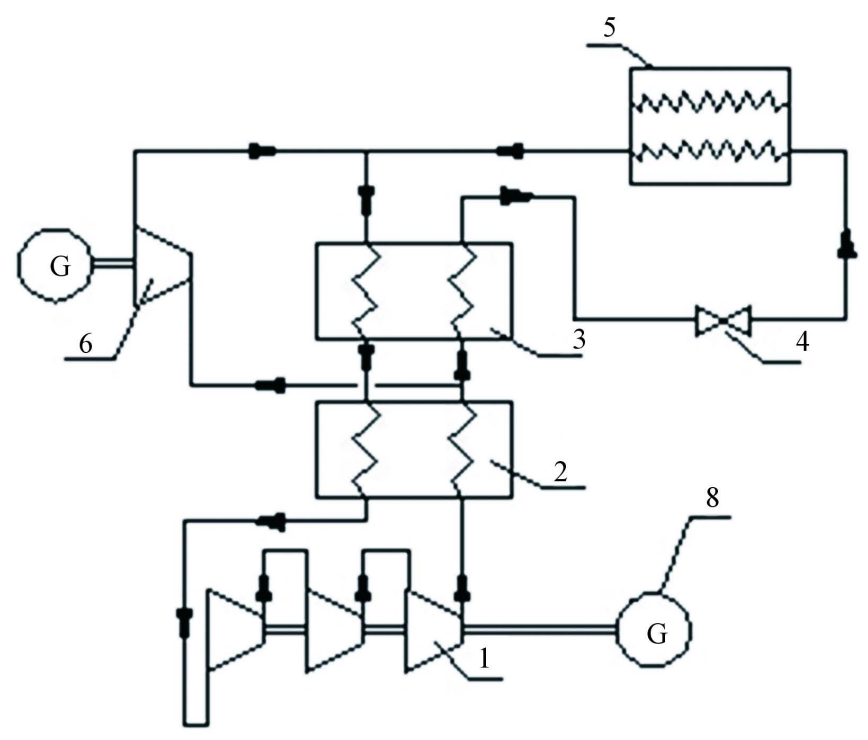

\begin{tabular}{|l|l|}
\hline 1 & 3 -stage compressor \\
\hline 2 & heat exchanger 1 \\
\hline 3 & heat exchanger 2 \\
\hline 4 & expansion valve \\
\hline 6 & turboexpander \\
\hline 8 & generator \\
\hline
\end{tabular}

Figure 2. System diagram of the Claude cycle driven by electricity.

As shown in Figure 2, the power of the electricity plant directly drives the compressor in the Claude cycle, gaseous nitrogen goes into first the heat exchanger (HX1) after the compressor has a total pressure boost, nitrogen from HX1 is divided into two parts, one part enters the turbine cooler to be cooled, another part of the nitrogen continues entering into the second heat exchanger (HX2) to be cooled into liquid nitrogen (the proportion of the nitrogen after turbine cooler calls the systems bypass rate, which is $x=0.55$ ), and then through the throttle valve into the boil-off gas condenser, exchange heat with the gaseous natural gas to be liquefied in BOG condenser (as shown in Figure 1), mix the nitrogen from boil-off gas condenser and the nitrogen from turbine cooler, the mixed nitrogen enters into the HX2, the HX1, finally enters into the compressor to complete this cycle.

\subsubsection{Gas Turbine Driven the Claude Cycle}

The gas turbine (Brayton cycle) to drag the Claude cycle to make the cooling capacity is showed in Figure 3.

As shown in Figure 3, figure, the Claude cycle in this system (Figure 3) and the Claude cycle in Figure 2 is almost same, the difference is that the Claude cycle in Figure 2 uses the electricity power to drive the compressor, while in Figure 3, it uses the gas turbine (Brayton cycle) to drive the compressor. The natural gas from the LNG tank is divided into two parts: one part is re-liquefied and goes back to LNG tank, another part of the gaseous natural gas as fuel to provide power for the gas turbine. The output work of gas turbine will drive the Claude cycle to make natural gas re-liquefaction in BOG heat exchanger.

\subsubsection{Internal-Combustion Engine Driven the Claude Cycle}

This system is similar to the Claude cycle which is driven by the electricity. The location of the generator is replaced by the internal combustion engine which drives the Claude cycle. The system is shown in Figure 4.

\section{Simulation Model}

In this paper, EES is used to simulated and calculate for the Re-liquefaction systems. 


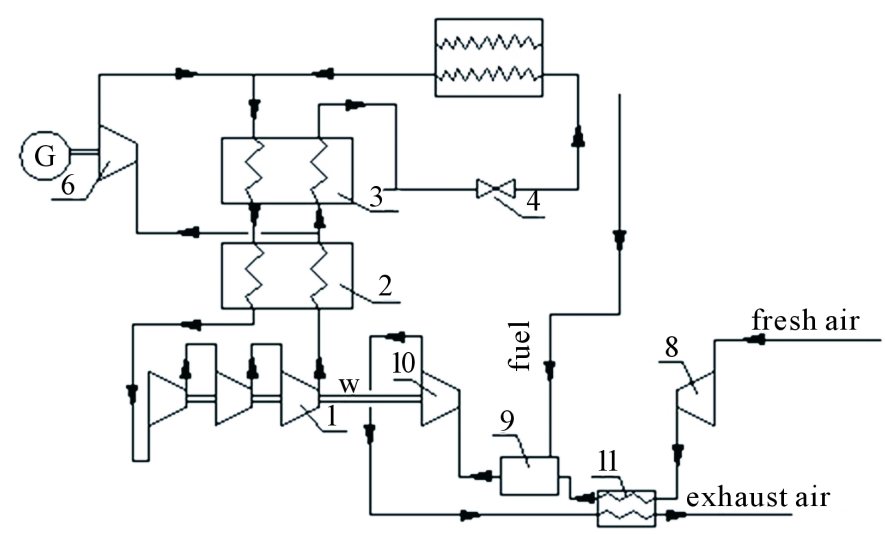

\begin{tabular}{|l|l|}
\hline 1 & 3 -stage compressor \\
\hline 2 & heat exchanger 1 \\
\hline 3 & heat exchanger 2 \\
\hline 4 & expansion valve \\
\hline 6 & turboexpander \\
\hline 8 & compressor \\
\hline 9 & combustion chamber \\
\hline 10 & Turbine \\
\hline 11 & heat exchanger 3 \\
\hline
\end{tabular}

Figure 3. System diagram of Claude cycle driven by gas turbine.

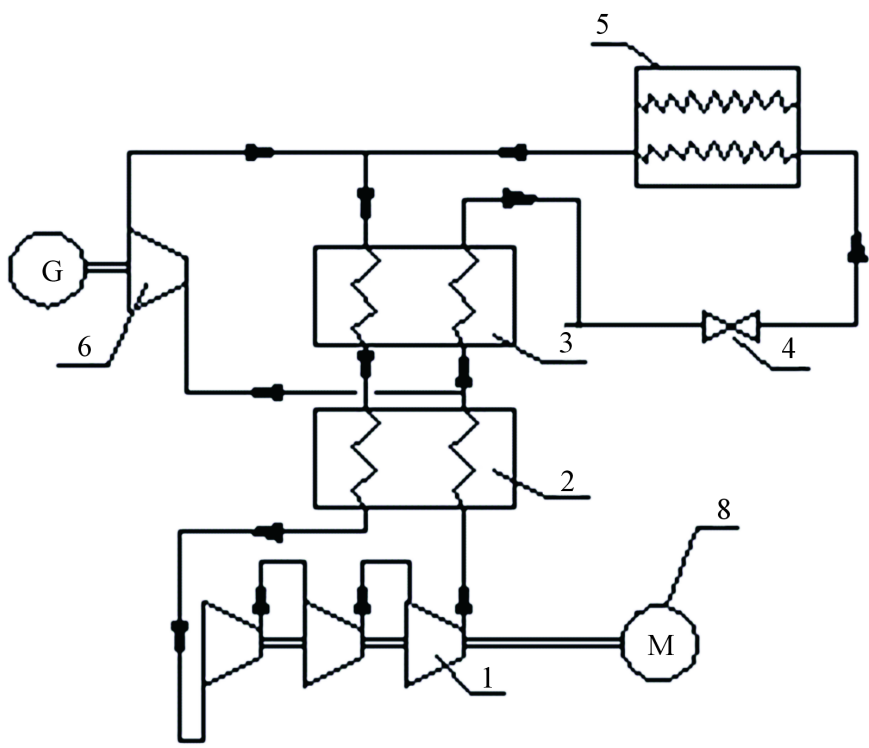

\begin{tabular}{|l|l|}
\hline 1 & 3 -stage compressor \\
\hline 2 & heat exchanger 1 \\
\hline 3 & heat exchanger 2 \\
\hline 4 & expansion valve \\
\hline 6 & turboexpander \\
\hline 8 & Internal combustion engine \\
\hline
\end{tabular}

Figure 4. System diagram of Claude cycle driven by internal combustion engine. 


\subsection{Burning NG Directly Released by BOG}

NG released by BOG is burning directly to keep the pressure of LNG tank under the pressure limit, the react equation is:

$$
\mathrm{CH}_{4}+2 \mathrm{O}_{2}=\mathrm{CO}_{2}+2 \mathrm{H}_{2} \mathrm{O}
$$

So, the greenhouse gas emissions produced through burning NG directly released by BOG can calculate according the following equation:

$$
V_{d}=\frac{m_{d} \times 11}{\rho \times 4} .
$$

\subsection{Electricity Driven Claude Refrigeration Cycle}

The source of the electricity generally comes from thermal power plants, and the major combustion of the thermal power plants is coal. The industrial analysis value of coal concludes fixed carbon $45 \%-50 \%$, internal moisture $3 \%$ - $4 \%$, ash $10 \%$ - 25\%, volatile $35 \%$ - 40\%, and calorific value $5800-6800 \mathrm{cal} / \mathrm{g}$, sulfur content $1 \%$ - $4 \%$. It is $\mathrm{C}$ and $\mathrm{O}_{2}$ reacts produce the greenhouse gas in the coal combustion process, the react equation is:

$$
\mathrm{C}+\mathrm{O}_{2}=\mathrm{CO}_{2}
$$

So, the greenhouse gas emissions produced by the Claude cycle driven by electricity power can calculate according the following equation:

$$
V_{e}=\frac{m_{e} \times a \times 11}{\rho \times 3} .
$$

\subsection{Gas Turbine Driven the Claude Cycle}

The gas turbine mainly burning NG as fuel to drive the Claude cycle to re-liquefied the natural gas, chemical reaction equation is:

$$
\mathrm{CH}_{4}+2 \mathrm{O}_{2}=\mathrm{CO}_{2}+2 \mathrm{H}_{2} \mathrm{O}
$$

So, the greenhouse gas emissions produced by the Claude cycle driven by gas turbine can calculate according the following equation:

$$
V_{b}=\frac{m_{b} \times 11}{\rho \times 4}
$$

\subsection{Internal Combustion Engine Driven Claude Cycle}

The combustion engines mainly burning natural gas as fuel to drive the cloud cycle to re-liquefied the natural gas, chemical reaction equation is:

$$
2 \mathrm{C}_{8} \mathrm{H}_{8}+25 \mathrm{O}_{2}=16 \mathrm{CO}_{2}+18 \mathrm{H}_{2} \mathrm{O} \text {. }
$$

So, the greenhouse gas emissions produced by the Claude cycle driven by internal combustion engine can calculate according the following equation:

$$
V_{i}=\frac{m_{i} \times 11}{\eta \times \rho \times 27}
$$

\section{Greenhouse Gas Emissions (GGE) Analysis}

\subsection{Relationship between the Gas Flow and the Greenhouse Gas Emissions}

When the flow of the directly discharge of gaseous NG ranges from $30 \mathrm{~kg} / \mathrm{h}$ to $50 \mathrm{~kg} / \mathrm{h}$, the amount of greenhouse gas of igniting the directly discharge of gaseous NG from NG tank and using the Claude cycle driven by different powers is showed in Figure 5: 


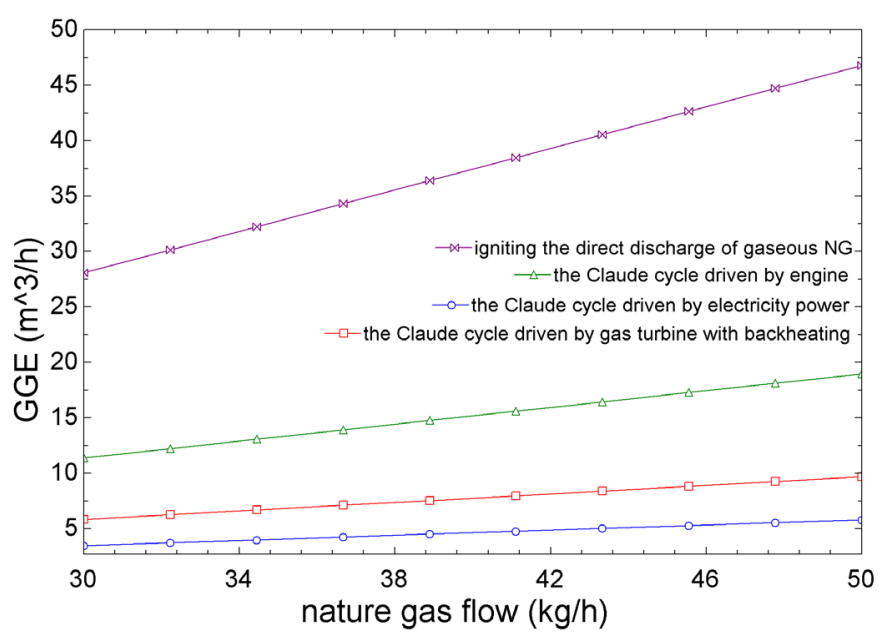

Figure 5. Relationship between the gas flow and the greenhouse gas emissions.

It is known from the Figure 5 that with the increasing of natural gas boil-off gas flow, the greenhouse gas emissions (GGE) of the three systems and igniting the discharge of gaseous NG increases. The GGE from high to low is as follows: igniting the discharge of gaseous NG, the Claude cycle driven by the Internal combustion engine, the Claude cycle driven by the electricity power and the Claude cycle driven by the gas turbine. This is because with the nature gas flow increasing, the system needs more fuel, in turn, the emissions of greenhouse gas increasing.

It is also showed from the Figure 5 that the amount of greenhouse gas of igniting the directly discharge of gaseous NG from NG tank is much more than the amount of greenhouse gas by using the re-liquefaction systems. And the amount by using the re-liquefaction systems is for most $46 \%$ of the amount of greenhouse gas of igniting the directly discharge of gaseous NG, the least only $11.5 \%$.

\subsection{The Relationship between Evaporation Temperature of the Claude Cycle and the Greenhouse Gas Emissions}

When the LNG tank volume is $220,000 \mathrm{~m}^{3}$, the gasification rate is $0.15 \%$, and the evaporation temperature of the Claude cycle ranges from $-130^{\circ} \mathrm{C}$ to $-150^{\circ} \mathrm{C}$, the greenhouse gas emissions of the three systems are showed in Figure 6.

As shown in Figure 6, it is concluded that along with the increase of the evaporation temperature, the greenhouse gas emissions (GGE) decreases on the contrary. At the same evaporation temperature, the GGE from high to low is still as follows: the Claude cycle driven by the Internal combustion engine, the Claude cycle driven by the electricity power and the Claude cycle driven by the gas turbine. For the same natural gas flow rate (i.e. the heat of exothermic liquefaction is certain) and BOG condenser at the nitrogen side has the same inlet temperature, with the evaporation temperature increasing, the required refrigerant flow becomes smaller, finally the power of the compressor becomes smaller, so the greenhouse gas emissions decrease. But the increase of the evaporation temperature is influenced by the NG liquefaction temperature, it may not be increased without limit, so GGE has the minimum value.

\subsection{The Relationship between the LNG Tank Volume, BOR and the Greenhouse Gas Emissions}

When the LNG tank volume is $220,000 \mathrm{~m}^{3}$, the gasification rate ranges from $0.1 \%$ to $0.3 \%$, the greenhouse gas emissions of the three systems are showed in Figure 7.

When the gasification rate of the LNG tank is $0.15 \%$, the volume of natural gas pool range from 100,000 to $300,000 \mathrm{~m}^{3}$, the greenhouse gas emissions of the three systems are showed in Figure 8 .

As shown in above figures, it can be known that when the LNG tank volume is fixed, with the gasification rate increasing, the greenhouse gas emissions of the three systems also increase; when the BOR of the LNG tank 


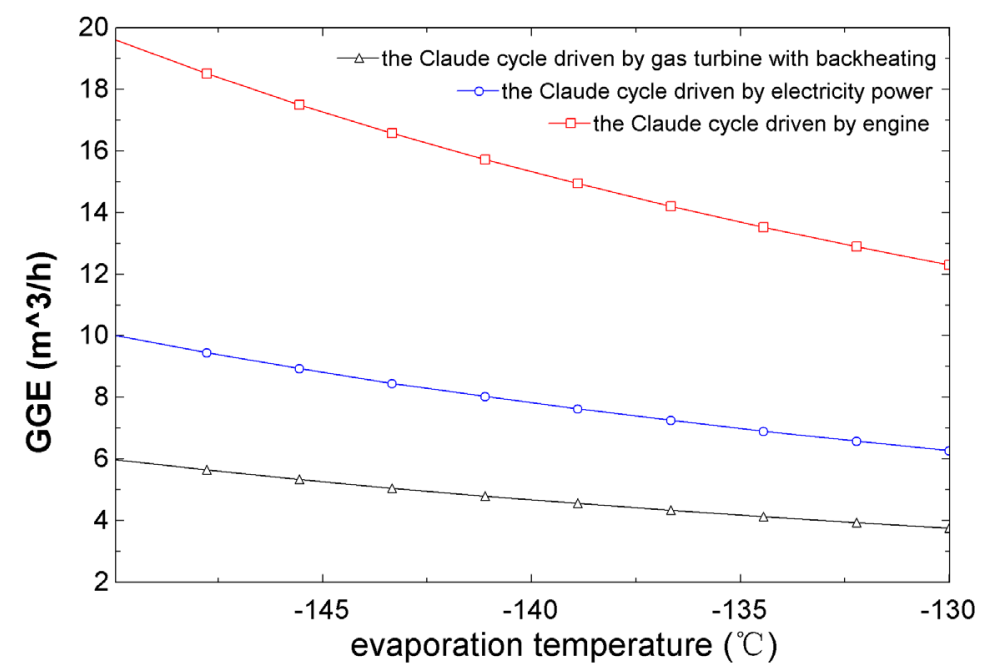

Figure 6. Relationship between evaporation temperature and greenhouse gas emissions.

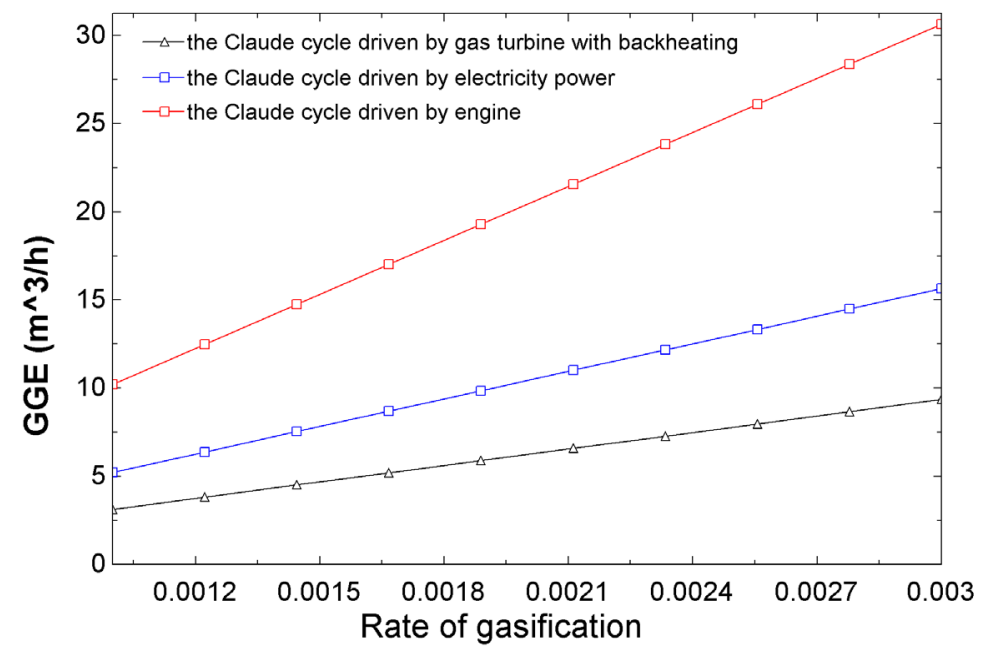

Figure 7. Relationship between the power and the gasification rate.

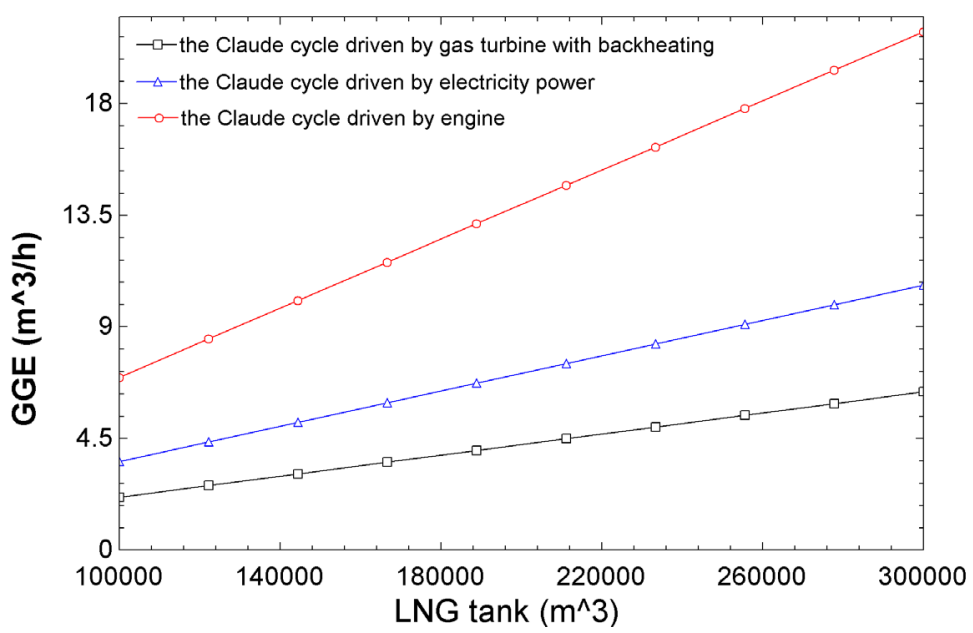

Figure 8. Relationship between the power and the LNG tank volume. 
is certain, with the increase of the LNG tank volume, the greenhouse gas emissions of the three systems also increase. A greenhouse gas emission depends on natural gas tank. More gaseous natural gas means producing more greenhouse gas. However, under the same conditions, the emission of the internal combustion engine is much more than the other two systems and the minimum emission is the Claude cycle driven by gas turbine. This is because of internal combustion engine efficiency is generally low and using gasoline as fuel, which has more carbon atoms, so the internal engine produces much more greenhouse gases. The Claude cycle driven by gas turbine, by contrast, is the best choice.

\section{Sample Discussion}

The design of the LNG boil-off gas re-liquefaction plant has been performed base on the nominal LNG boil-off gas rate (BOR) of $0.15 \%$ of cargo capacity per day for a $220,000 \mathrm{~m}^{3}$ (Full tank filling) LNG carriers. The inlet temperature and pressure of the BOG (boil-off gas) condenser at the BOG side are set to $-49.63^{\circ} \mathrm{C}$ and $3.25 \mathrm{bar}$, respectively. The outlet temperature and pressure of BOG condenser at the BOG side are $-161^{\circ} \mathrm{C}$ and $3.0 \mathrm{bar}$, respectively. The characteristics of the BOG are in the Table 1.

The system uses the electricity of power plant to drive the compressor of Claude cycle to make the liquefied process of natural gas. For the same electricity generating units, the quality of the coal directly determines the efficiency of power generation. The composition and calorific value of coal is listed in Table 2 [17].

Taking the Datong soft coal in the nationwide highest calorific value to calculate, for most of the thermal power plants, one $\mathrm{kW} \cdot \mathrm{h}$ generally require $0.3 \mathrm{~kg}$ coals, now a large unit can be up to $0.27 \mathrm{~kg}$ per $\mathrm{kW} \cdot \mathrm{h}$. While the calorific value of coal is certain, it is defined that every kilograms coal containing 29,306 kJ (7000 kcal) thermal energy as the standard coal as known. Select the lowest operating cost as the calculation basis, for the specific volume $\left(220,000 \mathrm{~m}^{3}\right)$ of the LNG tank, specific gasification rate $(0.15 \%)$.

For the Claude cycle drives by electricity power, gas turbine, internal combustion engine, the inlet temperature and pressure at the nitrogen side of the BOG condenser are $-163^{\circ} \mathrm{C}$ and $14.6 \mathrm{bar}$, the outlet temperature and pressure are $-140^{\circ} \mathrm{C}$ and 14.5 bar.

According to the given conditions, calculate the greenhouse gas emissions of the three ways are:

Burning NG directly released by BOG: GGE $=30.15 \mathrm{~m}^{3} / \mathrm{h}$;

The electricity power drives the Claude cycle: $\mathrm{GGE}_{\mathrm{e}}=10.67 \mathrm{~m}^{3} / \mathrm{h}$;

The gas turbine with regenerative drives the Claude cycle: $\mathrm{GGE}_{\mathrm{b}}=6.378 \mathrm{~m}^{3} / \mathrm{h}$;

The engine drives the Claude cycle: $\mathrm{GGE}_{\mathrm{i}}=20.9 \mathrm{~m}^{3} / \mathrm{h}$.

According to the theory calculation, it is known that in the three ways of making natural gas re-liquefied, the Claude cycle driven by the gas turbine has the minimum greenhouse gas emissions.

\section{Conclusions}

In this paper, it introduces three kinds of different natural gas (NG) re-liquefaction systems and analyzes the greenhouse gas emissions (GGE) of the three different systems by controlling liquefied natural gas volume per unit time, and then it is concluded as follows:

1) The amount of greenhouse gas of igniting the directly discharge of gaseous NG from NG tank is much more than the amount of greenhouse gas by using the re-liquefaction systems. And the amount by using the re-liquefaction systems is for most $46 \%$ of the amount of greenhouse gas of igniting the directly discharge of gaseous NG, the least only $11.5 \%$.

2) For the three kinds of NG re-liquefaction systems, the greenhouse gas emissions (GGE) from high to low is: the internal combustion engine drives the Claude cycle to make natural gas re-liquefied, the electricity drives the Claude cycle to make natural gas re-liquefied and the gas turbine with the regenerator drives the Claude cycle to make natural gas re-liquefied.

3) When gaseous natural gas flow rate is small, the greenhouse gas emissions (GGE) is small; With the increasing of natural gas boil-off gas flow, the greenhouse gas emissions (GGE) of the three systems increases. The GGE from high to low is as follows: the Claude cycle driven by the Internal combustion engine, the Claude cycle driven by the electricity power and the Claude cycle driven by the gas turbine.

4) In the Claude cycle, with the evaporation temperature increasing, the greenhouse gas emissions (GGE) decreases on the contrary. So in the actual operating system, the evaporation temperature of the Claude cycle should be tried to rise. But with the limit of the liquefied natural gas temperature, the evaporation temperature 
Table 1. Characteristics table of the natural gas.

\begin{tabular}{ccccccccc}
\hline & $\begin{array}{c}\text { MassFrac. } \\
\text { (methane) }\end{array}$ & $\begin{array}{c}\text { Mass Frac } \\
(\text { nitrogen) }\end{array}$ & $\begin{array}{c}\text { Mass Frac } \\
(\text { ethane) }\end{array}$ & $\begin{array}{c}\text { Temperature } \\
\left({ }^{\circ} \mathrm{C}\right)\end{array}$ & $\begin{array}{c}\text { Pressure } \\
(\mathrm{bar})\end{array}$ & $\begin{array}{c}\text { Density } \\
\left(\mathrm{kg} / \mathrm{m}^{3}\right)\end{array}$ & $\begin{array}{c}\text { Enthalpy } \\
(\mathrm{kj} / \mathrm{kg})\end{array}$ & $\begin{array}{c}\text { Entropy } \\
(\mathrm{kj} / \mathrm{kg} \cdot \mathrm{k})\end{array}$ \\
\hline Gaseous state & 0.92560 & 0.074100 & 0.0003000 & -49.630 & 3.2500 & 2.9393 & 706.58 & 5.5822 \\
Liquid state & 0.92560 & 0.074100 & 0.0003000 & -161.00 & 3.0000 & 434.14 & -1.7144 & 0.36019 \\
\hline
\end{tabular}

Table 2. Properties of coal in China.

\begin{tabular}{|c|c|c|c|c|c|c|c|c|}
\hline \multirow{2}{*}{ Types of coal } & \multicolumn{7}{|c|}{ Elemental composition } & \multirow{2}{*}{$\begin{array}{l}\text { Calorific value } \\
(\mathrm{kJ} / \mathrm{kg})\end{array}$} \\
\hline & $\mathrm{M}_{\mathrm{ar}}$ & $\mathrm{A}_{\mathrm{ar}}$ & $\mathrm{C}_{\mathrm{ar}}$ & $\mathrm{H}_{\mathrm{ar}}$ & $\mathrm{O}_{\mathrm{ar}}$ & $\mathrm{N}_{\mathrm{ar}}$ & $\mathrm{S}_{\mathrm{ar}}$ & \\
\hline Blind coalin JingXi & 5.0 & 22.8 & 67.9 & 1.7 & 2.0 & 0.4 & 0.2 & 23,040 \\
\hline Blind coal in YangQuan & 5.0 & 19.0 & 68.9 & 2.9 & 2.4 & 1.0 & 0.8 & 26,400 \\
\hline Soft coal in DaTong & 3.0 & 11.7 & 70.8 & 4.5 & 7.1 & 0.7 & 2.2 & 27,800 \\
\hline Soft coal in XinWen & 6.0 & 18.8 & 61.0 & 4.1 & 6.8 & 1.4 & 1.9 & 25,140 \\
\hline Soft coal in XuZhou & 10.0 & 13.5 & 63.0 & 4.1 & 6.7 & 1.5 & 1.2 & 24,720 \\
\hline Midding coal in LongFengXi & 15.0 & 29.8 & 42.9 & 3.4 & 7.5 & 0.9 & 0.5 & 16,760 \\
\hline Lignite in FengGuang & 22.0 & 25.7 & 35.2 & 3.2 & 12.6 & 1.1 & 0.2 & 13,410 \\
\hline
\end{tabular}

cannot increase without limit, in the range of the system design temperature, GGE has the minimum value.

5) When the LNG tank and the BOR are certain, the gas turbine has the minimum greenhouse gas emissions.

\section{References}

[1] Yang, Z.H. (2011) Economic Growth, the Dynamic Relationship between Energy Consumption and $\mathrm{CO}_{2}$ Emissions. The Journal of World Economy, 6, 100-125.

[2] Lin, B.Q. and Jiang, Z.J. (2009) The Predict and Influence Factors Analysis of the Kuznets Curve in Chinese Carbon Dioxide Environment. Management World, 4, 27-36.

[3] Shin, M.W., Shin, D., Choi, S.H. and Yoon, E.S. (2008) Optimal Operation of the Boil-Off Gas Compression Process Using a Boil-Off Rate Model for LNG Storage Tanks. Korean Journal of Chemical Engineering, 25, 7-12. http://dx.doi.org/10.1007/s11814-008-0002-9

[4] Sinha, R.P. and Norsani, W.M. (2012) Investigation of Propulsion System for Large LNG Ships. 1st International Conference on Mechanical Engineering Research 2011 (ICMER2011), Materials Science and Engineering, 36, 1-16.

[5] Seo, M. and Jeong, S. (2010) Analysis of Self-Pressurization Phenomenon of Cryogenic Fluid Storage Tank with Thermal Diffusion Model. Cryogenics, 50, 549-555. http://dx.doi.org/10.1016/j.cryogenics.2010.02.021

[6] Khemis, O., Boumaza, M., Ait Ali, M. and Francois, M.X. (2003) Experimental Analysis of Heat Transfers in a Cryogenic Tank without Lateral Insulation. Applied Thermal Engineering, 23, 2107-2117. http://dx.doi.org/10.1016/S1359-4311(03)00164-9

[7] Moon, J.W., Lee, Y.P., Jin, Y.W., Hong, E.S. and Chang, H.M. (2007) Cryogenic Refrigeration Cycle for Re-Liquefaction of LNG Boil-Off Gas. International Cryocooler Conference, Inc., Boulder, 629-635.

[8] Querol, E., Gonzalez-Regueral, B., García-Torrent, J. and Ramos, A. (2011) Available Power Generation Cycles to Be Coupled with the Liquid Natural Gas (LNG) Vaporization Process in a Spanish LNG Terminal. Applied Energy, 88, 2382-2390. http://dx.doi.org/10.1016/j.apenergy.2011.01.023

[9] Chin, Y.W. (2006) Cycle Analysis on LNG Boil-Off Gas Re-Liquefaction Plant. Journal of the Korea Institute of Applied Superconductivity and Cryogenics, 8, 34-38.

[10] Baek, S., Hwang, G., Lee, C., Jeong, S. and Choi, D. (2011) Novel Design of LNG (Liquefied Natural Gas) Reliquefaction Process. Energy Conversion and Management, 52, 2807-2814. http://dx.doi.org/10.1016/j.enconman.2011.02.015

[11] Shin, Y. and Lee, Y.P. (2009) Design of a Boil-Off Natural Gas Reliquefaction Control System for LNG Carriers. Applied Energy, 86, 37-44. http://dx.doi.org/10.1016/j.apenergy.2008.03.019

[12] Pil, C.K., Rausand, M. and Vatn, J. (2008) Reliability Assessment of Reliquefaction Systems on LNG Carriers. Reliability Engineering and System Safety, 93, 1345-1353. http://dx.doi.org/10.1016/j.ress.2006.11.005 
[13] Sayyaadi, H. and Babaelahi, M. (2010) Thermoeconomic Optimization of a Cryogenic Refrigeration Cycle for Re-Liquefaction of the LNG Boil-Off Gas. International Journal of Refrigeration, 33, 1197-1207. http://dx.doi.org/10.1016/j.ijrefrig.2010.03.008

[14] Sayyaadi, H. and Babaelahi, M. (2011) Multi-Objective Optimization of a Joule Cycle for Re-Liquefaction of the Liquefied Natural Gas. Applied Energy, 88, 3012-3021. http://dx.doi.org/10.1016/j.apenergy.2011.03.041

[15] Romero, J., Orosa, J.A. and Oliveira, A.C. (2012) Research on the Brayton Cycle Design Conditions for Reliquefaction Cooling of LNG Boil off. Journal of Marine Science and Technology, 17, 532-541. http://dx.doi.org/10.1007/s00773-012-0180-3

[16] O’Brien, J.E. and Siahpush, A. (1998) Investigation of Low-Cost LNG Vehicle Fuel Tank Concepts. Idaho National Engineering and Environmental Laboratory Final Report, FGFU-98/0015.

[17] Wang, X.H. (2003) The Choice and Analysis of the Technology of Nitrogen Liquification Equipments, Coal Chemical Industry. 8.

\section{Nomenclature}

$V_{e} \quad$ The greenhouse gas emission of electricity driven Claude refrigeration cycle;

$m_{e} \quad$ The quantity of the coal burned per hour;

a The mass fraction of the carbon in the coal;

$V_{d} \quad$ The greenhouse gas emission of burning NG directly;

$m_{d} \quad$ The quantity of the NG burned per hour of burning NG directly;

$\rho \quad$ The density of the $\mathrm{CO}_{2}$;

$V_{b} \quad$ The greenhouse gas emission of gas turbine driven the Claude cycle;

$m_{b} \quad$ The quantity of the natural gas burned per hour to drive gas turbine;

$V_{i} \quad$ The greenhouse gas emission of the system of internal combustion engine;

$m_{i} \quad$ The quantity of the gasoline burned per hour of internal combustion engine;

$\eta \quad$ The thermal efficiency of the internal combustion engine. 